\section{(6) OPEN ACCESS}

\title{
A novel immunodeficiency syndrome associated with partial trisomy $19 \mathrm{p} 13$
}

\author{
Markus G Seidel, ${ }^{1}$ Celia Duerr, ${ }^{2}$ Stavroula Woutsas, ${ }^{3}$ Anette Schwerin-Nagel, ${ }^{4}$ \\ Kambis Sadeghi, ${ }^{2}$ Jürgen Neesen, ${ }^{5}$ Sabine Uhrig, ${ }^{6}$ Elisangela Santos-Valente, ${ }^{3}$ \\ Winfried F Pickl, ${ }^{7}$ Wolfgang Schwinger, ${ }^{1}$ Christian Urban, ${ }^{1}$ Kaan Boztug, ${ }^{2,3}$ \\ Elisabeth Förster-Waldl ${ }^{2}$
}

- Additional material is published online only. To view please visit the journal online (http://dx.doi.org/10.1136/ jmedgenet-2013-102122).

For numbered affiliations see end of article.

\section{Correspondence to} Kaan Boztug, M.D.,

CeMM Research Center for Molecular Medicine Lazarettgasse 14, AKH BT 25.3, 1090 Vienna, Austria kboztug@cemm.oeaw.ac.at; Elisabeth Förster-Waldl, M.D. Division of Neonatology, Paediatric Intensive Care \& Neuropaediatrics, Department of Paediatrics and Adolescent Medicine, Medical University Vienna, Währinger Gürtel 18-20; 1090 Vienna, Austria; Elisabeth.foerster-wald|@ meduniwien.ac.at: Markus G. Seidel, M.D., Division of Pediatric Hematology-Oncology, Department of Pediatrics and Adolescent Medicine, Medical University Graz, Austria, Auenbruggerpl. 38; 8036 Graz, Austria; markus.seidel@medunigraz.at

MGS, CD, KB and EF-W contributed equally to this study.

Received 21 October 2013 Revised 4 December 2013 Accepted 16 December 2013 Published Online First 15 January 2014

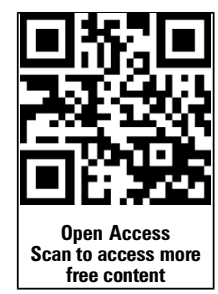

To cite: Seidel MG, Duerr C, Woutsas S, et al. J Med Genet 2014:51: 254-263.

\section{ABSTRACT \\ Background Subtelomeric deletions and duplications may cause syndromic disorders that include features of immunodeficiency. To date, no phenotype of immunological pathology has been linked to partial trisomy 19. We report here on two unrelated male patients showing clinical and laboratory signs of immunodeficiency exhibiting a duplication involving Chromosome 19p13.}

Methods Both patients underwent a detailed clinical examination. Extended laboratory investigations for immune function, FISH and array comparative genome hybridization (CGH) analyses were performed.

Results The reported patients were born prematurely with intrauterine growth retardation and share clinical features including neurological impairment, facial dysmorphy and urogenital malformations. Array CGH analyses of both patients showed a largely overlapping terminal duplication affecting Chromosome 19p13. In both affected individuals, the clinical course was marked by recurrent severe infections. Signs of humoral immunodeficiency were detected, including selective antibody deficiency against polysaccharide antigens in patient 1 and reduced $\lg G_{1}, \lg G_{3}$ subclass levels and IgM deficiency in patient 2. Class-switched B memory cells were almost absent in both patients. Normal numbers of $T$ cells, B cells and natural killer cells were observed in both boys. Lymphocytic proliferation showed no consistent functional pathology, however, function of granulocytes and monocytes as assessed by oxidative burst test was moderately reduced. Moreover, natural killer cytotoxicity was reduced in both patients. Immunoglobulin substitution resulted in a decreased number and severity of infections and improved thriving in both patients.

Conclusions Partial trisomy 19p13 represents a syndromic disorder associating organ malformation and hitherto unrecognised immunodeficiency.

\section{INTRODUCTION}

Numerical chromosomal aberrations have long been known to be potentially associated with primary immunodeficiency. Well-known syndromes include trisomy 21 as well as Turner's syndrome $(45, \mathrm{X} 0)$ (reviewed in $\left.{ }^{1}\right)$. In addition, a number of chromosomal microdeletion syndromes have been described with known immunodeficiency phenotype, including DiGeorge phenotypes associated with $22 \mathrm{q} 11.2$ or $10 \mathrm{p} 13-14$ microdeletion $^{1}{ }^{2}$ or Wolf-Hirschhorn syndrome ( $4 \mathrm{p}$ partial deletion). ${ }^{13}$

By contrast, microduplication events have rarely been associated with immunodeficiency. Microduplications within the short arm of chromosome 19 are rare: between 1980 and 2010, a total of 10 patients with partial trisomy $19 \mathrm{p} 13$ have been reported. $^{4-13}$ We here present an extension of the phenotype of partial trisomy 19 involving Chromosome 19p13. Two unrelated patients of non-consanguineous background with known syndromic features associated with partial trisomy 19 additionally displayed a marked immunodeficiency status prompting immunoglobulin (Ig) substitution therapy. In syndromic disorders, obvious organ malformation or dysfunction may be the leading clinical phenotype and thus mask immunodeficiency.

\section{METHODS}

For Methods including cytogenetics please see the online supplementary material.

\section{Patient presentation, clinical course and immunological investigations}

We report on two independent patients from two different University Clinics in Austria, whose similarities were noticed in the context of an ongoing collaboration within the Austrian Society of Pediatric Immunology.

Birth, anatomical malformations and growth

Patient 1, a 7-year-old boy was born prematurely in the 32nd week of gestation after an uneventful pregnancy $(32+2$ weeks, intrauterine growth retardation (IUGR), caesarean section, oligohydramnion) with $990 \mathrm{~g}$ body weight $(<3 \%), 34 \mathrm{~cm}$ body length $(<3 \%)$, and a head circumference of $26.5 \mathrm{~cm} \mathrm{(<3 \% );} \mathrm{his} \mathrm{APGAR} \mathrm{score} \mathrm{was} \mathrm{8/9/9;} \mathrm{he}$ was discharged from neonatal intensive/intermediate care at the chronological age of 8 weeks. He is the second child to non-consanguineous healthy parents of Turkish descent aged 34 years (mother) and 40 years (father). The second patient, a now 2-year-old boy, was born prematurely as the second child of a 29-year-old Austrian mother and a 35 -year-old Austrian father after an uneventful (third) pregnancy at $31+1$ weeks of gestational age (IUGR, caesarean section, APGAR 7/8/9, $660 \mathrm{~g}$ birth weight $(<3 \%), 34 \mathrm{~cm}$ length $(<3 \%), 26.5 \mathrm{~cm}$ head circumference $(<3 \%))$; dismissed from 
Table 1 Genetic and clinical synopsis of two patients with partial trisomy 19 (19p13.3)

\begin{tabular}{|c|c|c|}
\hline & Patient 1 & Patient 2 \\
\hline Cytogenetic aberration & $\begin{array}{l}46, X Y \text {.ish der(14)t(14;19)(p11.2;p13.2)de novo; partial trisomy of } \\
\text { the telomeric part of the short arm of chromosome 19, which is } \\
\text { translocated to the short arm of chromosome } 14\end{array}$ & $\begin{array}{l}46, X Y \text {.ish der(16)t }(16 ; 19)(p 13.3 ; p 13.3) \\
\text { balanced translocation; } \\
\text { array-CGH: microduplication 19p, microdeletion } 16 p\end{array}$ \\
\hline $\begin{array}{l}\text { Chromosomal break points } \\
\text { (min-max) }\end{array}$ & (arr(hg19) 19p13.3p13.2(90 897-7 300 043)×3) & $\begin{array}{l}\text { (arr(hg19)16p13.3(106 271-1 } 024153 \times 1) \\
\text { 19p13.3(327 273-6 } 887622 \times 3)\end{array}$ \\
\hline Size (max) & $7.2 \mathrm{Mb}(19 \mathrm{p})$ & $6.56 \mathrm{Mb}(19 \mathrm{p})$ and $0.92 \mathrm{Mb}(16 \mathrm{p})$ \\
\hline $\begin{array}{l}\text { Gestational age (week+day); } \\
\text { APGAR }\end{array}$ & $\begin{array}{l}\text { 32+2; IUGR, caesarean section, anhydramnion; } \\
\text { 8/9/9; RDS }\end{array}$ & $\begin{array}{l}\text { 31+1; IUGR, caesarean section; } \\
7 / 8 / 9 \text {; wet lung; }\end{array}$ \\
\hline Birth weight (g; percentile) & $990 ;<3 \%$ & $660 ;<3$ \\
\hline Birth length ( $\mathrm{cm}$; percentile) & $34 ;<3 \%$ & $34 ;<3$ \\
\hline $\begin{array}{l}\text { Birth head circumference }(\mathrm{cm} \text {; } \\
\text { percentile) }\end{array}$ & $26,5:<3 \%$ & 23,$5 ;<3$ \\
\hline $\begin{array}{l}\text { Current age and growth status; } \\
\text { body weight/length/head } \\
\text { circumference }\end{array}$ & $\begin{array}{l}\text { Current age: } 78 / 12 \text { years } \\
19 \mathrm{~kg} ;<3 \% / 110 \mathrm{~cm} ;<3 \% / \text {.d. }\end{array}$ & $\begin{array}{l}24 \text { months; } \\
7,77 \mathrm{~kg} ;<<3 \% / 75 \mathrm{~cm} ;<3 \% / 42 \mathrm{~cm} ;<<<3 \%\end{array}$ \\
\hline $\begin{array}{l}\text { Head and neck face, ears, eyes, } \\
\text { nose, mouth }\end{array}$ & $\begin{array}{l}\text { Microcephalus, flat nasal bridge, telecanthus, low set ears, and } \\
\text { long philtrum, strabismus convergens alternans }\end{array}$ & $\begin{array}{l}\text { Microcephalus, flat nasal bridge, telecanthus, short upslanting } \\
\text { palpebral fissures, long eyelashes, strabismus, hypermetropia, long } \\
\text { philtrum, narrow/thin lips, micrognathia and pharyngeal instability; } \\
\text { strabismus, hypermetropia }\end{array}$ \\
\hline Cardiovascular & Unremarkable & Persisting ductus arteriosus of borderline haemodynamic relevance \\
\hline Abdomen & Bilateral incarcerated inguinal hernia & Bilateral inguinal hernia \\
\hline Genitourinary & $\begin{array}{l}\text { Perineal hypospadia (grade IV) Snodgras surgery (at } 5 \text { years of } \\
\text { age); penoscrotal fistula (urethral stent at } 6 \text { years) }\end{array}$ & $\begin{array}{l}\text { Glandular hypospadia (grade I), hydrocele vaginalis testis; } \\
\text { maldescensus testis; horseshoe kidney }\end{array}$ \\
\hline Skeletal & $\begin{array}{l}\left.\text { Severe osteopenia (z-score: }-4.6\left[0,26 / \mathrm{cm}^{3}\right]\right) \text {, developmental } \\
\text { dysplasia of the hip IV A Pemberton's acetabuloplasty }\end{array}$ & $\begin{array}{l}\text { Camptodactylia of both toes II, IV and V with overlapping of the right } \\
\text { IVth toe }\end{array}$ \\
\hline Skin, nails hair & Unremarkable & Sparse hair (borderline normal at 24 months), clubbed nails and skin \\
\hline Neurological & $\begin{array}{l}\text { Profound motor and mental retardation, brainstem evoked } \\
\text { response audiometry (BERA): sensorineural hearing loss, habitual } \\
\text { primarily generalised seizures (EEG-verified epilepsy, pathology } \\
\mathrm{III}^{\circ} \text { ) cranial MRI: hypoplastic inferior vermis and a slightly } \\
\text { extended temporal lobe, otherwise normal. }\end{array}$ & $\begin{array}{l}\text { Profound motor and mental retardation; mild muscular hypotonia; } \\
\text { automated auditory brainstem response (AABR-ALGO): normal. } \\
\text { Two short generalised seizures in the context of suspected meningitis, } \\
\text { EEG basal activity inadequate, otherwise normal, no focal activity; } \\
\text { cranial MRI: multiple diffuse hyperintense white matter lesions, } \\
\text { pronounced atrophy, hydrocephalus e vacuo, normal corpus callosum, } \\
\text { microcystic lesion in basal ganglia; otherwise normal. }\end{array}$ \\
\hline
\end{tabular}

IUGR, intrauterine growth retardation; arr cgh, array comparative genome hybridization; RDS, respiratory distress syndrome.

neonatal intensive/intermediate care at 3 months of chronological age (corrected gestational age: $42+6$ weeks). Growth parameters, weight and head circumference of both patients have remained below the third centile, recent measurements are presented in table 1 . The parents and siblings of both patients are healthy, and the extended family histories are negative for syndromic disorders or immunodeficiency.

Upon birth, both patients showed visible organ malformations including microcephalus, facial dysmorphism including flat nasal bridge, telecanthus, short upslanting palpebral fissures, low set ears, long philtrum, narrow lips, micrognathia (figure $1 \mathrm{~A}, \mathrm{C}$ ), as well as urogenital malformations, a perineal hypospadia in patient 1 (figure 1B) and glandular hypospadia, horseshoe kidney, cryptorchism (table 1), camptodactylia on both feet of toes II, III, IV and overlapping of right third/fourth toes (figure 1D) in patient 2.

\section{Clinical course and neurodevelopmental status}

In his 1 st year of life, patient 1 suffered from a bilateral incarcerated inguinal hernia and thus had to undergo surgery. Additionally, he showed developmental hip dysplasia type IVa, which was surgically treated by Pemberton's acetabuloplasty. At the age of 5 years, hypospadia required surgery whereupon a penoscrotal fistula was detected that could not be fully corrected.

An extensive neurological examination in the 2 nd year of life (chronological age: 18 months) showed profound neurological impairment and motor plus mental retardation. Neuropaediatric examination revealed muscular hypotonia, reduced muscle strength, brisk deep tendon reflexes, negative Babinski sign; furthermore, at 18 months the boy was unable to sit, to crawl, nor to stand free; and, without further specification, the neurological report mentions showed reduced fine motor skills and speech/language retardation., Testing of the sensory system and cerebellar function was unfeasible. Moreover, a strabismus convergens alternans of the left eye was noted at the age of 18 months. Additionally, moderate bilateral sensorineural hearing loss was detected by brainstem evoked response audiometry (summarised in table 1). Cranial MRI showed a hypoplastic inferior vermis and a slightly extended temporal lobe (data not shown). Furthermore, the patient suffered from EEG-verified epilepsy (habitual primarily generalised seizures, EEG pathology $\mathrm{III}^{\circ}$ ) treated with valproate, which resulted in decrease of frequency of seizures (not shown). Later neurological evaluations focused on the antiepileptic treatment, while ongoing physiotherapy and ergotherapy have been aiming to improve the psychomotor situation. Dysphagia prompted the implantation of a percutaneous endoscopic gastrostomy tube at the age of 6 years. Because of a severe osteopenia (z score: -4.6 $\left(0.26 / \mathrm{cm}^{3)}\right)$ resulting in a pathological fracture at the age of 6 years, he is treated with bisphosphonate intravenously $(18 \mathrm{mg})$ every 3 months.

Similar to patient 1 , patient 2 suffered from inguinal hernia leading to bilateral herniotomy at $3 \frac{1}{2}$ months of age. He was noted to have a persisting ductus arteriosus with marginal 
Figure 1 Images of phenotypical details. (A) facial dysmorphy and (B) perineal hypospadia in patient 1. (C) facial dsymorphy including long philtrum and narrow lips and (D) syndactylia of right third/forth toes in patient 2. (a)

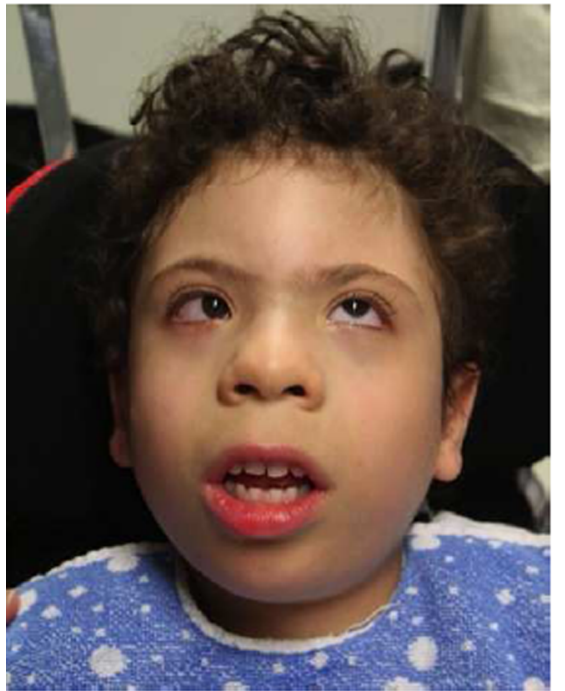

(c)

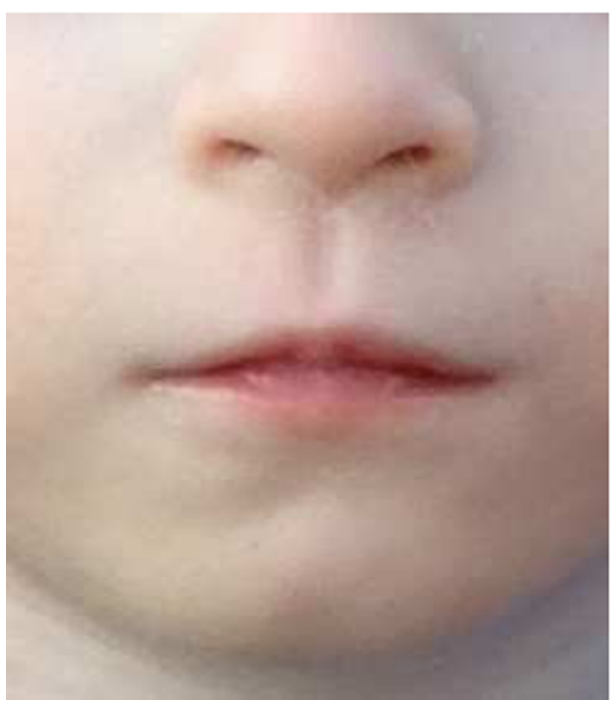

(b)

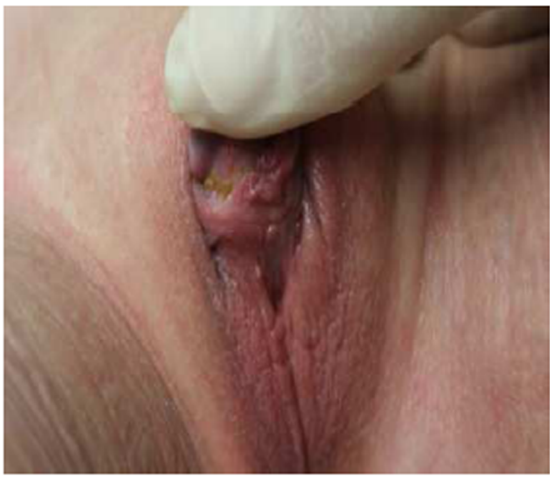

(d)

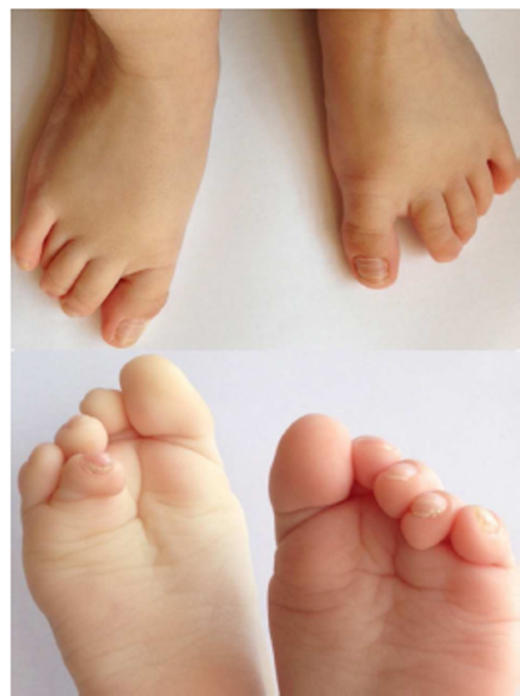

haemodynamic relevance. Because of delayed motor and mental development (see below), progressive failure to thrive and feeding problems, intensive physiotherapy and ergotherapy was provided, additional nasogastric tube feeding with formula diet was initiated at 8 months and percutaneous gastrostomy was performed at 20 months. Like patient 1 , he is neurologically and intellectually impaired with profound psychomotor retardation and muscular hypotonia (eg, sitting and belly sliding/ crawling only at 2 years of age; grabbing a spoon without ability to use it), speech delay (vocalising only syllables like 'da' at 2 years), pharyngeal instability, microcephalus, had neonatal seizures treated with barbiturate for 10 days and two generalised seizures in the context of suspected meningitis leading to temporal antiepileptic treatment with levetiracetam, from 18 months to 21 months of age. Denver test analysis at 2 years of age revealed social contact abilities corresponding to 15 months and motor skills corresponding to 6-9 months. Basal EEG activity was found to be mildly abnormal without focal activity, and in CNS-MRI profound atrophy with multiple diffuse white matter lesions and microcystic alterations of the basal ganglia were detected (table 1). Additionally, patient 2 suffers from hypermetropia and divergent concomitant strabismus, largely resembling patient 1 ; however hearing tests were normal.
Clinical signs of immunodeficiency and immune dysregulation

Both patients fulfilled the classical and revised criteria of a primary immunodeficiency disorder with frequent infections ${ }^{14-17}$ and showed laboratory signs of immune dysregulation. Starting from the age of 3 weeks after birth, patient 1 developed recurrent invasive bacterial infections including episodes of sepsis; a proven Staphylococcus capitis sepsis at the age of $1 \frac{1}{2}$ years was followed by a severe urosepsis at 3 years. Apart from two episodes of pneumonia, chronic relapsing productive bronchitis with laboratory signs of bacterial infections recurred more than eight times per year, requiring inpatient admittance and intravenous antibiotic treatment. Moreover, the boy suffered from recurrent urinary tract infections possibly related to the hypospadia, with microbiological evidence of extended-spectrum beta lactamase (ESBL)-positive-positive Escherichia coli infection on two instances. Considering the clinical history of repeated severe bacterial infections in this patient, laboratory investigations revealing selective antibody deficiency and decreased numbers of class-switched B cells (see below), ${ }^{18}$ he was started on intravenous immunoglobulin $(0.4 \mathrm{~g} / \mathrm{kg}$, at monthly intervals) at 5 years of age. This resulted in a significant decrease in the occurrence of infections, especially of the upper respiratory tract and lower respiratory tract. 
Patient 2 suffered from relapsing viral bronchiolitis and required frequent hospitalisations for intravenous antibiotics because of recurrent severe infections (invasive pneumonia, frequent episodes of febrile otitis media, bronchitis with bacterial superinfection, two episodes of suspected meningitis with seizures required intensive care (see table 1). Upon immunological investigations hypogammaglobulinaemia was diagnosed and immunoglobulin substitution commenced according to evidencebased guidelines for the treatment of primary antibody deficiencies. ${ }^{18}$ Intravenous immunoglobulin treatment was used from 20 months of age $(0.4 \mathrm{~g} / \mathrm{kg}$ monthly) and switched to subcutaneous Ig substitution (SCIG; 160-200 mg/kg weekly), resulting in reduced frequency and severity of infections and improved thriving. Recently, patient 2 developed protracted enteropathy with calprotectin concentrations in stool $>1800 \mu \mathrm{g} / \mathrm{g}$ (normal $<50$ $\mu \mathrm{g} / \mathrm{g}$ ), which may potentially indicate inflammatory bowel disease and awaits further evaluation by endoscopy and histology.

\section{Immunological laboratory investigations}

Both patients showed clear signs of humoral immunodeficiency in accordance with the clinical pattern of infections and presence of autoantibodies: in patient 1 , global immunoglobulin levels and IgG subclasses were adequate for age (tables 2 and 3), but specific antibodies against pneumococcal antigens remained low after vaccination (table 3). Despite absence of clinical signs of autoimmunity, positive antinuclear and anticytoplasmatic autoantibodies (ANA and ANCA, resp.) were detected in patient 1 (table 2). Basic cellular immunological findings showed no overall quantitative alterations in T cell, B cell or natural killer (NK) cell counts. In order to further investigate the capacity of patients' B cells to perform a class switch and develop memory responses, CD27 expression and $\operatorname{IgD}$ expression were investigated as described previously. ${ }^{19}{ }^{20}$ This revealed that class switched B memory cells were reduced (table 4, figure 2A). In patient 2, humoral immunological abnormalities were more pronounced: overall IgG levels were mildly reduced with clear reduction of $\operatorname{IgG}_{1}$ and $\operatorname{IgG}_{3}$ subclasses and IgM, while IgA was normal (tables 1 and 3). Moreover, patient 2 had highly increased anti-double-stranded DNA antibodies $(32 \mathrm{IU} / \mathrm{mL}$; normal 0-15 $\mathrm{IU} / \mathrm{mL}$ ) and subclinical autoimmune thyroiditis on repeated occasions with high concentrations of thyroperoxidase antibodies (>1000 U/mL, normal: 0-60 U/L), thyroid stimulating hormone receptor antibodies ( $>100 \mathrm{U} / \mathrm{L}$, normal: $0-15 \mathrm{U} / \mathrm{L}$; table 4$)$ and mildly increased thyroid stimulating hormone $5.89-8.6 \mu \mathrm{U} / \mathrm{mL}$ (normal $0.1-4.0 \mu \mathrm{U} / \mathrm{mL}$ ) but normal thyroxin and only mildly elevated trijodthyronine. Additionally, 21-hydroxylase autoantibodies and glutamate decarboxylase autoantibodies were positive, suggesting imminent polyendocrinopathy as a potential sign of immune dysregulation in patient 2 .

Cellular investigations revealed absolute numbers of T cells, B cells and NK cells to be normal in patient 2 , however similar to patient 1 , class switched B memory cells were substantially reduced (table 4 and figure $2 \mathrm{~B}$ ), suggesting a $\mathrm{B}$ cell maturation defect. While $\mathrm{T}$ cell proliferative responses were initially within normal range in both boys, recent data revealed a reduced $\mathrm{T}$ cell proliferation upon stimulation in vitro in the older patient $1 . \mathrm{T}$ cell receptor (TCR) excision circle analysis as a marker of thymic function showed no reduction, and $\mathrm{T}$ cell receptor $\mathrm{V} \beta$ repertoire to assess TCR rearrangement was unremarkable (table 4). NK cell cytotoxicity as determined by CD107a degranulation was borderline low in both patients, while cytotoxic T cell cytotoxicity was normal (table 4). Granulocyte and monocyte oxidative burst assays showed a moderate reduction (table 4). Complement activity was normal in both boys, but mannan-binding lectin (MBL) was practically absent in patient 2, yielding impaired lectin-associated complement activation. In patient 1, although basal MBL serum concentration was borderline normal, genotype analysis of $M B L 2$ and its promoter showed polymorphisms that are usually associated with inadequate MBL production (table 3).

Table 2 Laboratory abnormalities and treatment of two patients with partial trisomy 19 (19p13.3)

\begin{tabular}{|c|c|}
\hline & Patient 1 \\
\hline Endocrine & $\begin{array}{l}\text { TSH: mildly increased }(7.06 \mu \mathrm{U} / \mathrm{mL}(0.66-4.1 \mu \mathrm{U} / \mathrm{mL})) \text {; } \\
\text { thyroxine and trijodthyronine normal; parathormone: normal } \\
\text { 25-hydroxy-vitamin D3: decreased; bone specific alkaline } \\
\text { phospatase: } 22.5 \mathrm{ng} / \mathrm{mL}(50-100 \mathrm{ng} / \mathrm{mL})\end{array}$ \\
\hline $\begin{array}{l}\text { Immunology, main features } \\
\text { (see tables } 3 \text { and } 4 \text { for } \\
\text { complete lab) }\end{array}$ & $\begin{array}{l}\text { Immunoglobulin levels were adequate for age, selective } \\
\text { antibody deficiency against polysaccharide antigens, no } \\
\text { alterations in T cell, B cell or NK cell counts } \\
\text { in vitro T cell proliferation reduced; borderline low } \\
\text { class-switched B memory cells. } \\
\text { NK degranulation: low, CTL normal. } \\
\text { Granulocytic oxidative burst assays demonstrated a moderate } \\
\text { reduction, whereas monocytic respiratory burst was decreased. } \\
\text { MBL reduction; CH50/AH50: normal }\end{array}$ \\
\hline
\end{tabular}

Other laboratory abnormalities ANA and ANCA positive

Other (phenotypical) features Malnutrition due to dysphagia: PEG tube feeding since 6 years of age

Treatment

\section{Patient 2}

Latent autoimmune thyroiditis with suspected inhibitory TSH-receptor autoantibodies; thyroxin normal and trijodthyronine borderline elevated; glutamate-decarboxylate-autoantibodies: $70.7 \mathrm{U} / \mathrm{L}$ (0-9.5 U/L) parathormone: normal

25-hydroxy-vitamin D3: normal

HGH: reduced; IGF1, IGFBP3: normal

Borderline hypogammaglobulinaemia; $\lg _{1}, \lg _{3}$ subclass deficiency IgM deficiency

vaccination antibodies (Diph., Tet., Pneumoc., Haemophilus inf.B, HBV) normal

$T$ cells: reduced total count, normal subsets and in vitro proliferation; decreased class-switched B memory cells.

NK and CTL degranulation: NK reduced, CTL normal

granulocyte/monocyte function (DHR): borderline reduced $(94-80 \%$ of normal, respectively)

MBL defect; CH50/AH50 normal

ds-DNA and thyroid antibodies;

$\alpha$-thalassaemia minor (due to microdeletion 16p; NOT including the TSC2, PKD or RTS genes)

Malnutrition due to feeding problems: PEG tube feeding since 20th month of age

IVIG from 20th month (4-weekly) until 23 months;

Ig subcutaneous started at 23 months (160-200 mg/kg Ig subcutaneous weekly); levetiracetam 
Table 3 Humoral immune phenotype of two patients with partial trisomy 19 (19p13.3)

\begin{tabular}{|c|c|c|}
\hline (Age-specific institutional normal ranges)* & patient 1 see footnotes for age & patient $2+$ \\
\hline \multicolumn{3}{|l|}{ Before substitution; (mg/dL) } \\
\hline $\lg G$ & $1362(473-1385) \ddagger$ & $386(442-918)$ \\
\hline $\lg G_{1}$ & $952(370-1000) \ddagger$ & $270(290-820)$ \\
\hline $\lg G_{2}$ & $231(72-340) \ddagger$ & $100(38-240)$ \\
\hline $\operatorname{lgG}_{3}$ & $74(13-133) \ddagger$ & $6(15-107)$ \\
\hline $\operatorname{lgG}_{4 d}$ & $106(0-158) \ddagger$ & $3(0-62)$ \\
\hline $\lg A(m g / d L)$ & $70(39-147) \ddagger$ & $61(2-98)$ \\
\hline $\operatorname{lgM}(\mathrm{mg} / \mathrm{dL})$ & $131(20-92) \ddagger$ & $0.07(12-104)$ \\
\hline $\lg E(I U / m L)$ & $4.6(0-100] \ddagger$ & 5.7 \\
\hline $\lg D(\mathrm{mg} / \mathrm{L})$ & $6.43 \ddagger$ & 6.4 \\
\hline Antitetanus toxoid $\operatorname{lgG}(\mathrm{IU} / \mathrm{mL})$ & $6.94 \ddagger$ & 4.42 \\
\hline Antidiphtheria toxoid IgG (IU/mL) & $0.43 \ddagger$ & 1.35 \\
\hline \multicolumn{3}{|l|}{ Antipneumococci capsule polysaccharide } \\
\hline Antibodies (after threefold 13-valent conjugated vaccine) & titers:: IgG: 1:94; IgM:1:300 & $\begin{array}{l}\text { IgG concentration: } \\
166.88 \mathrm{mg} / \mathrm{L}\end{array}$ \\
\hline Antihaemophilus influenzae b lgG (mg/L) & $9 \ddagger$ & 3.23 \\
\hline \multirow[t]{2}{*}{ Antimeningococci $\mathrm{C}$ antibodies (after $1-\times$ conjugated MenC vaccine): } & $\lg G \ddagger: 1: 105$ & n.d. \\
\hline & $\lg M \ddagger: 1: 28$ & \\
\hline Anti hepatitis B IgG & n.d. & $>1000 \mathrm{mlU} / \mathrm{mL}$ \\
\hline Anti EBV-lgG & n.d. & neg. \\
\hline Anti CMV-lgG & n.d. & neg. \\
\hline Anti varicella-lgG & n.d. & $48 \mathrm{mlU} / \mathrm{mL}$ \\
\hline CH50/AH50 (U/mL) & $>300 \ddagger$ & n.d. \\
\hline Mannan-binding lectin (MBL) (ng/mL) & $273(>300) \ddagger$ & $17.8(>300)$ \\
\hline $\begin{array}{l}\text { MBL2 genotype: analysis of five genomic polymorphisms: codon } 52 \text { (CGT>TGT); codon } 54 \\
(\mathrm{GGC}>\mathrm{GAC}) ; \text { codon } 57(\mathrm{GGA}>\mathrm{GAA}) \text {; promoter }-550(\mathrm{G}>\mathrm{C}) \text {; promoter }-221(\mathrm{G}>\mathrm{C})\end{array}$ & $\begin{array}{l}\text { LXA/LYB; ( }=\text { codon } 54 \text { homozygous and } \\
\text { promoter }-550 \text { heterozygous polymorphism) }\end{array}$ & n.d. \\
\hline $\begin{array}{l}\text { *Normal ranges in square brackets; pathological results in bold letters. } \\
\text { †At repeated occasions between } 20 \text { months and } 24 \text { months of age. } \\
\text { ‡Between the age of } 4 \text { years and } 5 \text { years. } \\
\text { §At } 3 \text { years. } \\
\text { १At } 6 \text { years. } \\
{ }^{* *} \text { At } 7 \text { years of age. } \\
\text { ††According to the manufacturer's instructions; invitrogen/LifeTechnologies Vienna, Austria. } \\
\text { MBL, mannan-binding lectin. }\end{array}$ & & \\
\hline
\end{tabular}

\section{Other laboratory abnormalities}

Additional laboratory investigations in patient 1 revealed hypovitaminosis D3 corresponding to clinical signs of osteopenia and latent hypothyreosis. Because patient 2 had mild anaemia with haemoglobin levels of $10 \mathrm{~g} / \mathrm{dL}$ including microcytosis (mean corpuscular volume 69fl) and hypochromia (mean corpuscular haemoglobin 20pg; mean corpuscular haemoglobin concentration $29 \mathrm{~g} / \mathrm{dL}$ ) despite normal iron metabolism (ferritin and transferrin normal), and because his chromosomal aberration showed to involve the haemoglobin $\alpha$ chain locus on $16 \mathrm{p}$, he was suspected to have $\alpha$ thalassaemia minor. Haemoglobinopathy workup revealed no clinically relevant haemoglobinopathy (normal $\mathrm{Hb}$-electrophoresis, normal $\mathrm{HbA}, \mathrm{HbF}, \mathrm{HbA2}$ ), but genetic data (see below) and the microcytic hypochromic anaemia were compatible with $\alpha$ thalassaemia trait (genotype $-/ \alpha \alpha$ ).

Together, these findings (1) confirm and extend what is known on anatomical and neurodevelopmental abnormalities, and (2) newly describe a complex immunodeficiency phenotype involving mainly a memory $\mathrm{B}$ cell and humoral defect with increased risk of infections and features of immune dysregulation in patients with partial trisomy $19 \mathrm{p} 13$.

\section{Genetic assessment}

Results of CGH array, performed as described elsewhere, ${ }^{21}$ were annotated using Human Genome Build GRCh37/hg19.
Genes within the break points were taken from http://www. ensembl.org ${ }^{22}$ and filtered for protein-coding genes only. CGH analysis of patient 1 revealed a $7.2 \mathrm{Mb}$ terminal duplication of the short arm of chromosome 19 ( $\operatorname{arr}(\mathrm{hg} 19) 19 \mathrm{p} 13.3 \mathrm{p} 13.2$ $(90897-7300043) \times 3)$. This region contains 211 known protein-coding genes (see online supplementary table S1). Moreover, FISH revealed a translocation from chromosome 19 to chromosome $14(46, X Y$.ish $\operatorname{der}(14) \mathrm{t}(14 ; 19)(\mathrm{p} 11.2 ; \mathrm{p} 13.2) \mathrm{de}$ novo) (figure $2 \mathrm{C}$ ).

$\mathrm{CGH}$ analysis of patient 2 showed a $6.56 \mathrm{Mb}$ terminal duplication of the short arm of chromosome 19 (see online supplementary table S1) combined with a partial $0.92 \mathrm{Mb}$ deletion of Chromosome $16 \mathrm{p} 13$ including a total of 45 protein-encoding genes (see online supplementary table S2) (( $\operatorname{arr}(\mathrm{hg} 19) 16 \mathrm{p} 13.3$ (106 271-1 024 153)×1,19p13.3(327 273-6 887 622)×3)). FISH revealed an unbalanced translocation from chromosome 19 to chromosome 16 (46,XY.ish $\operatorname{der}(16) \mathrm{t}(16 ; 19)(\mathrm{p} 13.3$; p13.3)) (figure 2D). Parents of patient 2 and his older healthy sister did not consent to and thus did not undergo genetic analysis. The duplicated region of $19 \mathrm{p} 13$ consists of 200 proteincoding genes all of which were also contained in the duplicated region from patient 1 (figure $2 \mathrm{E}$ ). By contrast, the duplication in patient 2 did not include several genes duplicated in patient 1, including OR4F17, PPAP2C, MIER2, EMR1, AC025278.1, MBD3L5, MBD3L4, MBD3L2, MBD3L3, ZNF557 and INSR. 
Table 4 Cellular immune phenotype and autoantibodies of two patients with partial trisomy 19 (19p13.3)

\begin{tabular}{|c|c|c|}
\hline (Age-specific institutional normal ranges)* & Patient 1 see footnotes for age & Patient $2+$ \\
\hline CD3 T cells/ $\mu \mathrm{L}$ & $3780(900-4500) \ddagger$ & $1212(1800-3000)$ \\
\hline CD3CD4 T cells/ $\mu \mathrm{L}$ & $1850(500-2400) \ddagger$ & $730(1000-1800)$ \\
\hline CD3CD8 T cells/ $\mu \mathrm{L}$ & $1430(300-1600) \ddagger$ & $198(800-1500)$ \\
\hline CD4CD45RA+/ $\mu \mathrm{L} ; \%$ of CD3CD4: & $610 ; 30 \% \S$ & $628 ; 86 \%$ \\
\hline TREC copies/100.000 CD3CD45 & 11.400 (high)§ & 99.700 (high) \\
\hline $\boldsymbol{\gamma}-\boldsymbol{\delta} \mathrm{TCR} C D 3 / \mu \mathrm{L} ; \%$ of CD3 & $90 ; 1.8 \% \S$ & $7 ; 0.6$ \\
\hline $\begin{array}{l}\text { TCR V } \boldsymbol{\beta} \text { repertoire }(\mathbf{n}=25) \\
\text { complexity score }(\max 125) \text { in } C D 4 \text { and CD8 T cells, resp.; clonality }\end{array}$ & $\begin{array}{l}110 \text { and } 112 \S ; \text { few oligoclonal and monoclonal, } \\
\text { three missing. }\end{array}$ & $\begin{array}{l}118 \text { and } 118 ; \\
\text { one oligoclonal and one missing }\end{array}$ \\
\hline In vitro $\mathrm{T}$ cell proliferation & Normal & \\
\hline Induced by PHA/ConA/CD3 Ab/SEA/SEB/PMA & reduced§ (PHA, CD3 Ab, SEA) & All normal \\
\hline iNKT cells $\%$ of CD3(Va24Vb11+TCR CD3CD56) & n.d & $1.19(>0.02)$ \\
\hline NK cells/ $\mu \mathrm{L}$ & $290(100-1000) \uparrow$ & $162(200-600)$ \\
\hline CD19+ B cells $/ \mu \mathrm{L}$ & $2640(200-2100) \uparrow$ & $770(700-1300)$ \\
\hline CD27lgD- B cells $\%$ of CD19;absolute $/ \mu \mathrm{L}$ & $\begin{array}{l}0 .{ }^{\prime} 35 \%(>2 \%) \uparrow ; \\
<1 / \mu \mathrm{L}(16-66 / \mu \mathrm{L}) \uparrow \\
1 \%(>2 \%) \S ; \\
20 / \mu \mathrm{L}(16-66)^{4}\end{array}$ & $\begin{array}{l}0.85 \%(>2 \%) \\
7 / \mu L(16-51 / \mu L)\end{array}$ \\
\hline CD27+lgD+ B cells $\%$ of CD19+;absolute $/ \mu \mathrm{L}$ & $\begin{array}{l}0.57 \%(>2 \%) q_{i} \\
10 / \mu \mathrm{L}(23-87 / \mu \mathrm{L}) \uparrow \\
2.3 \% ;(>2 \%) \S ; \\
60 / \mu \mathrm{L}(23-87 / \mu \mathrm{L}) \S\end{array}$ & $\begin{array}{l}1.44 \%(>2 \%) \\
11 / \mu \mathrm{L}(35-120 / \mu \mathrm{L})\end{array}$ \\
\hline $\begin{array}{l}\text { NK cytotoxicity: } \\
\text { CTL cytotoxicity: } \\
\text { (in vitro stimulated CD107a degranulation) }\end{array}$ & $\begin{array}{l}6.49 \%(>5-10 \%) \S \\
8.24 \%(>2.8-6.9 \%) \S\end{array}$ & $\begin{array}{l}2.68 \%(>5-10 \%) \\
4.44 \%(>2.8-6.9 \%)\end{array}$ \\
\hline 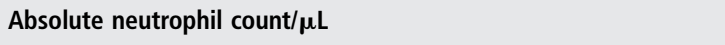 & 11 090(1800-7700)ף & $7300(1800-7700)$ \\
\hline Monocytes / $\mu \mathrm{L}$ & 1580 (400-1000)ף & $692(400-1000)$ \\
\hline $\begin{array}{l}\text { Phagocyte function: } \\
\text { phagocytosis (cells Escherichia coli opsonised) }\end{array}$ & $\begin{array}{l}\text { Granulocytes: normal** } \\
\text { granulocytes: normal§ } \\
\text { monoytes: normal§ }\end{array}$ & $\begin{array}{l}\text { Escherichia coli FITC: } 94.3 \% \\
\text { (>95) } \\
\text { DHR123: } 99 \%(>95 \%)\end{array}$ \\
\hline $\begin{array}{l}\text { Oxidative burst } \\
\text { (cells stimulated with PMA, fMLP) }\end{array}$ & $\begin{array}{l}\text { Granulocytes: fMLP-stimulated: reduced** } \\
\text { granulocytes: normal§ } \\
\text { monocytes: fMLP-stimulated: abnormal§ }\end{array}$ & $\begin{array}{l}\text { Escherichia coli FITC: } 79.2 \% \\
\text { (>80) } \\
\text { DHR123: } 81.9 \% \\
(>80)\end{array}$ \\
\hline $\begin{array}{l}\text { Granulocyte function 'time course' } \\
\text { method: Granulo FC Oxy Bursttt: }\end{array}$ & $\begin{array}{l}\text { Up to } 50 \% \text { reduced in comparison with } \\
\text { healthy controlq }\end{array}$ & n.d. \\
\hline \multicolumn{3}{|l|}{ Autoantibodies: } \\
\hline ANA/ENA screening & 1:40 /negative§ & negative/negative \\
\hline Double-strand DNA antibodies & Negative§ & $32.0 \mathrm{IU} / \mathrm{mL}(<10 \mathrm{IU} / \mathrm{mL})$ \\
\hline MPO-ANCA, Pr3-ANCA & ANCA 1:160 & Negative \\
\hline p-ANCA, c-ANCA & pos.§ & Negative \\
\hline Mitochondrial antibodies (AMAs, M2) & n.d. & Negative \\
\hline Smooth muscle antibodies (SMAs) & n.d. & Negative \\
\hline Liver autoantibodies screen (LKM1, LC1, SLA-LP, F-actin, gp210, sp100) & n.d. & Negative \\
\hline thyroperoxidase antibodies & n.d. & $>1000 \mathrm{U} / \mathrm{mL}(0-60 \mathrm{U} / \mathrm{mL})$ \\
\hline TSH receptor antibodies & n.d. & $>100 \mathrm{U} / \mathrm{mL}(0-15 \mathrm{U} / \mathrm{L})$ \\
\hline thyroglobulin antibodies & n.d. & negative \\
\hline glutamate-decarboxylase-antibodies & n.d. & $70.7 \mathrm{U} / \mathrm{L}(0-9.5 \mathrm{U} / \mathrm{L})$ \\
\hline 21-hydroxylase autoantibodies & n.d. & $1.3 \mathrm{U} / \mathrm{mL}(0.08-1.0 \mathrm{U} / \mathrm{L})$ \\
\hline
\end{tabular}

*Normal ranges in round brackets; pathological results in bold letters.

tAt repeated occasions between 20 months and 24 months of age.

$\ddagger$ At 3 years.

$\S$ At 7 years of age.

ๆAt 6 years.

**Between the age of 4 years and 5 years.

††According to the manufacturer's instructions; invitrogen/LifeTechnologies Vienna, Austria.

AMA, anti-mitochondrial antibodies; CTL, cytotoxic T lymphocytes; ENA, extractable nuclear antigen autoantibodies; fMLP, N-formylmethionyl-leucyl-phenylalanine; IFNg, interferon gamma; NK, natural killer; PHA, phytohaemagglutinin; PMA, phorbol-myristate acetate; TREC, T cell receptor excision circle; TSH, thyroid stimulating hormone.

\section{DISCUSSION}

To date, few chromosomal disorders have been associated with primary immunodeficiency diseases. ${ }^{1} 23$ The best known is 22q11.2 deletion syndrome, including a DiGeorge phenotype and Velo-Cardio-Facial syndrome. ${ }^{12}$ Besides characteristic syndromic dysmorphies, those patients develop no or a hypoplastic thymus, leading to defective thymocyte development. ${ }^{2}$ The degree of immunodeficiency varies between the affected patients up to severe combined immunodeficiency with cellular and humoral defects. ${ }^{2}$ Although $22 \mathrm{q} 11.2$ deletion is the most frequent deletion syndrome (incidence $1: 4000^{24}$ ), and a defect of a T-box family transcriptional regulator, TBX1, relevant during 
Figure 2 Immunological and genetic phenotype. Despite normal $B$ lymphocyte cell counts, IgD+CD27 and IgD-CD27 memory $B$ cells were nearly absent in patient 1 (A) as well as in patient 2 (B). FISH analysis of patient 1 showed partial trisomy 19 with additional material from chromosome $19 p$ on the short arm of chromosome 14 (C). FISH analysis of patient 2 revealed an unbalanced translocation from chromosome 19 to chromosome 16 (D). A schematic display of Chromsome 19 with an illustration of the duplicated regions in patients 1 and 2 , respectively (E).
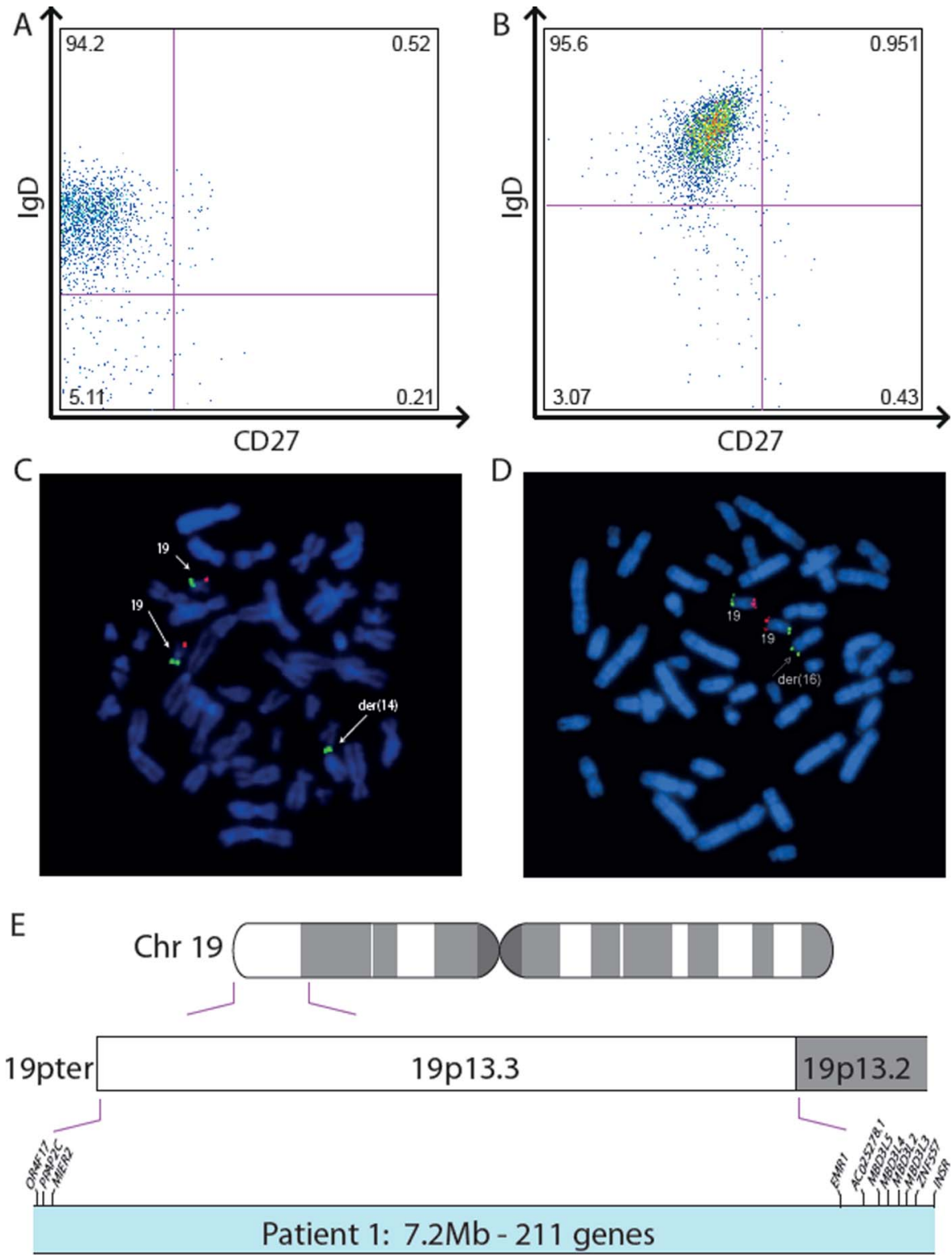

Patient 2: $6.6 \mathrm{Mb}-200$ genes organogenesis in mice and humans (reviewed in ${ }^{25}$ ) appears a candidate mechanism for $22 \mathrm{q} 11.2$ deletion syndrome, the genes that directly cause the involved immunodeficiency could not be identified so $\mathrm{far}^{2}$, which stresses the difficulty behind such intentions. Other microdeletion syndromes associated with impaired immunity include Wolf-Hirschhorn syndrome due to partial deletions of chromosome $4 \mathrm{p}^{13}$ and syndromes caused by deletion of chromosome 10p13-14 and partial deletions of chromosome $18 .^{1} 23$ In addition, patients with 45,X0 phenotype (Turner's syndrome) may present with antibody deficiency and an increased predisposition to autoimmunity. ${ }^{1}$

Immunodeficiency associated with partial or complete chromosomal duplications is rare with the exception of for example, duplication of methyl-CpG binding protein 2 (MECP2), a regulator of gene expression and chromatin structure encoded on Xq28, which leads to a complex syndrome with mild dysmorphia, intellectual disability, neurological deterioration and variable degrees of immunodeficiency (including impaired gamma interferon (IFNg) secretion and $\mathrm{T}$ helper cell type 1
(TH1) responses, reduced numbers of memory T cells, B cells and NK cells in children) as confirmed in human and murine studies. ${ }^{26}$ Another chromosomal duplication syndrome that has long been associated with increased susceptibility to infections, especially severe respiratory tract infections, is trisomy 21 . Those patients may show changes in thymus development and in B cell, $\mathrm{T}$ cell and NK cell counts, as well as low specific antibody response and granulocyte function. ${ }^{27}$

The present report is the first linking primary immunodeficiency to partial trisomy $19 \mathrm{p} 13$. The clinical and anatomical features of our patients are similar to reports on partial trisomy 19 p13.3 described previously, including IUGR, neurological impairment (profound psychomotor retardation, microcephalus, epilepsy, sensorineural hearing loss), facial dysmorphy (flat nasal bridge, telecanthus, short palpebral fissures, low set ears, long philtrum) and urogenital malformations. 4 6 7 9-11 13 The aforementioned publications often supplied only FISH mapping results (specific break points of the duplication were not examined), which makes it difficult to comparatively assess specific 
genes involved. ${ }^{4} 679-12$ More recently, Dolan et $a l^{8}$ described a patient with a microduplication within $19 \mathrm{p} 13.12-19 \mathrm{p} 13.2$ supporting a list of involved genes; however, the genes duplicated in the patients being different. Furthermore, one patient with a smaller $(0.81 \mathrm{Mb})$ duplication within $19 \mathrm{p} 13.3$ was reported, ${ }^{13}$ sharing similar features with our patients, including IUGR, microcephalus, psychomotor development delay, seizures accompanied by high fever, hyperopia and some facial features (flat nasal bridge, posteriorly angulated ears). Among the 24 protein-encoding genes of this interval which are also duplicated in both of our patients, the authors highlight MAP $2 K 2$ and $S E M A 6 B$, as being potentially involved in the dysmorphia and psychomotor phenotype. ${ }^{13}$ MAP2K2 encodes for a mitogenactivated protein kinase, and loss of function of this gene product has been associated with Cardiofaciocutaneous syndrome 4 (OMIM \#615280), a syndrome associating heart defects, facial dysmorphy and neurocognitive delay but no immunodeficiency. SEMA6B encodes semaphoring protein, which is involved in axon guidance and may contribute to the mental retardation observed in their patients. ${ }^{13}$

Intriguingly, previous publications lack laboratory results regarding the immune system. This is remarkable given that at least 2 of these 10 suffered from recurrent febrile episodes, ${ }^{10} 12$ 1 of whom died in early childhood of respiratory syncytial virus pneumonia, ${ }^{12}$ and 1 , additionally, had autoimmune disease. ${ }^{10}$

IgM deficiency may potentially contribute to the increased risk of upper and lower respiratory tract infections and autoimmunity as detected in combination with IgG subclass deficiency in patient 2. Although its relevance is uncertain as primary IgM deficiency may resolve spontaneously, it has been described in a number of syndromes with chromosomal abnormalities including microdeletion 22q11 (reviewed $\mathrm{in}^{28}$ ) and might represent another feature of impaired $\mathrm{B}$ cell maturation in partial trisomy $19 \mathrm{p} 13$.

Regarding the shared complex immune phenotype of our patients 1 and 2 with an increased frequency and severity of ear-nose-throat, upper and lower airway and invasive/systemic infections, compatible with the detected pathological immune phenotype of humoral and memory B cell deficiency, and moreover, reduced $\mathrm{NK}$ cell and phagocyte functions, the genes ELANE, TCF3, CD70 and C3 could be of particular interest. It remains speculative whether gene dosage might be involved in possible aberrant function of the respective gene products. ELANE, encoding neutrophil elastase, if mutated is known to cause severe congenital neutropenia, ${ }^{29} 30$ however the effect of a duplication of ELANE has not been investigated systematically. Although the described patients 1 and 2 have normal neutrophil counts, oxidative burst was moderately reduced in both cases.

TCF3, has been shown to play an important role in $\mathrm{T}$ cell and $\mathrm{B}$ cell differentiation ${ }^{31}$ and is involved in repeated chromosomal rearrangements connected with acute lymphoblastic leukaemia in children. ${ }^{32}$ Recently, a form of agammaglobulinaemia and absence of $\mathrm{B}$ cell antigen receptor was linked to deficiency of TCF3 (E2A), ${ }^{33}$ indicating that TCF3 might represent a candidate gene among the region of interest in the presented patients.

CD70 belongs to the tumour necrosis factor ligand family and binds to CD27 on B cells and T cells. ${ }^{34}$ CD70 is involved in cognate $\mathrm{T}-\mathrm{B}$ interaction and plays a key role in promoting the differentiation of CD27 memory B cells into plasma cells. ${ }^{35} \mathrm{~A}$ primary immunodeficiency involving loss-of-function mutations in CD27 has recently been associated with common variable immunodeficiency like immunodeficiency and EBV-driven lymphoproliferation. $^{20} 36$ Patients with common variable immunodeficiency show naïve $\mathrm{B}$ cells that cannot upregulate CD70, resulting in impaired class switch. ${ }^{34} 37$ TCF3 and CD70 might play a role in the pathogenesis in the patients described here, considering their reduced immunoglobulin levels and class-switched B memory cell numbers. Finally, among the duplicated genes, we find C3 encoding for complement factor 3 , necessary in alternative and classical complement activation pathways. ${ }^{38} \mathrm{C} 3$ deficiency is known to be associated with recurrent severe infections and in some cases with immune complexmediated autoimmune diseases. ${ }^{39}$

In contrast to the over $6 \mathrm{Mb}$ long duplication in both patients, the deleted region of patient 2 on $16 \mathrm{p} 13.3$ is much smaller $(0.92 \mathrm{Mb})$ and contains only 45 protein-encoding genes, notably comprising the $\alpha$ haemoglobin locus. As has been reported previously, deletions within 16pter-p13.3 may lead to $\alpha$-thalassaemia/ mental retardation syndrome (ATR-16, OMIM \#141750; 16pter-p13.3; for selected cases and review see ${ }^{40-42}$ ). Patient 2 presents with normal $\mathrm{Hb}$-electrophoresis, (normal $\mathrm{HbA}, \mathrm{HbF}$, $\mathrm{HbA} 2$ ) and mild microcytic hypochromic anaemia ( $\mathrm{Hb}$ around $10 \mathrm{~g} / \mathrm{dL}$, mean corpuscular volume of $69 \mathrm{fl}$, mean corpuscular haemoglobin of $20 \mathrm{pg}$, mean corpuscular haemoglobin concentration of $29 \mathrm{~g} / \mathrm{dL}$ ) corresponding to an $\alpha$ thalassaemia trait (genotype --/ $\alpha \alpha)$. Nevertheless, patients with ATR-16 are described to show only mild mental impairment and minor anomalies, which also differ between affected individuals and are not fully consistent with the characteristics of our patients 1 and $2 .^{41} 42$ Therefore we ascribe the outer appearance and mental retardation of patient 2 rather to the duplication of $19 \mathrm{p} 13$. This assumption is supported by the findings of Harteveld et $a l^{43}$, who focused on patients with ATR-16 without mental retardation and came to the conclusion that dysmorphic features and mental retardation are due to haploinsufficiency of an $800 \mathrm{~kb}$ region that does not overlap with the deletion of our patient 2 .

As the immunodeficiency in patient 1 had been recognised before birth of patient 2, an early administration of Ig substitution was initiated in patient 2 and possibly explains improved thriving and may have protected him from a history of more severe infections.

\section{CONCLUSION}

Taken together, these data expand the known clinical spectrum of partial trisomy $19 \mathrm{p} 13$ to include primary immunodeficiency, and we suggest the acronym FURID19 (Facial dysmorphia, Urogenital malformation, growth and neurodevelopmental Retardation, ImmunoDeficiency, trisomy $19 \mathrm{p} 13)$ for this syndrome. In general, immunodeficiency may be under-recognised in syndromic disorders, in particular in clinical situations where other features are prominent or implicate barrier dysfunctions. Thus, our findings underline that (1) patients with multiple malformations should undergo $\mathrm{CGH}$ array analysis and (2) patients with recurrent infections and syndromic features or microdeletions/microduplications should be tested for associated immunodeficiency to prevent a diagnostic and therapeutic delay and enable initiation of specific immunotherapy as early as possible.

\footnotetext{
Author affiliations

${ }^{1}$ Divison of Pediatric Hematology-Oncology, Department Pediatrics and Adolescent Medicine, Medical University Graz, Graz, Austria

${ }^{2}$ Divison of Neonatology, Paediatric Intensive Care \& Neuropaediatrics, Department Paediatrics and Adolescent Medicine, Medical University Vienna, Vienna, Austria

${ }^{3}$ CeMM Research Center for Molecular Medicine of the Austrian Academy of Sciences, Vienna, Austria

${ }^{4}$ Divison of General Pediatrics, Department Pediatrics and Adolescent Medicine, Medical University Graz, Graz, Austria

${ }^{5}$ Institute of Medical Genetics, Medical University of Vienna, Vienna, Austria

${ }^{6}$ Institute of Human Genetics, Medical University Graz, Graz, Austria

${ }^{7}$ Institute of Immunology, Medical University of Vienna, Vienna, Austria
} 
Acknowledgements The authors thank the patients and their families for understanding cooperation and giving their written informed consent to publish disease-specific data and features including photographs in the interest of advancing medical and scientific knowledge. Furthermore, fruitful discussions with Prof O A Haas and Prof M Speicher are highly appreciated and their scientific human genetic contribution to finalise the manuscript is acknowledged.

Contributors All authors state that they fulfil all of the following criteria for authorship: (1) Substantial contribution(s) to conception and design, acquisition of data, or analysis and interpretation of data; (2) Drafting the article or revising it critically for important intellectual content; and (3) Final approval of the version to be published. In detail and in addition to above points (1)-(3), ... authors state that:

MGS designed the study together with EF-W and $\mathrm{KB}$, wrote the initial version and the final draft of the manuscript, drafted the figures and tables, acquired, analysed, and interpreted clinical, laboratory, immunological and genetics data of patient 2, recognised phenotypical features and is in charge of the clinical care of patient 2. CD drafted significant parts of the manuscript, recognised phenotypical features and is in charge of the clinical care of patient 1. SW acquired, analysed, interpreted phenotypical and laboratory data and interpreted human genetics analyses of patients 1 and 2 together with $\mathrm{KB}$; additionally she drafted figures, tables and significant parts of the manuscript. ASN acquired, analysed and interpreted clinical neurological and laboratory, data, recognised phenotypical features and is in charge of the clinical care of patient 2 together with MGS.

ES-V performed experimental immunological assays in patient 1. KS interpreted clinical and immunological data, and is in charge of the clinical care of patient 1 together with EF-W and CD. JN acquired, analysed and interpreted clinical phenotypical and laboratory data, recognised phenotypical features and is in charge of human cytogenetics analyses of patient 1. SU acquired, analysed and interpreted clinical phenotypical and laboratory data, recognised phenotypical features and is in charge of human genetics analyses of patient 2. WFP generated and analysed immunological laboratory data. WS acquired, analysed and interpreted clinical, laboratory, and substantial amounts of immunological data of patients 1 and 2, and is in charge of the clinical care of patient 2. CU interpreted clinical, haematological laboratory, and substantial amounts of immunological data, and is in charge of the clinical care of patient 2. KB designed the study, acquired, analysed and interpreted immunological and genetics data of patients 1 and 2 , wrote the first draft and the revised version of the manuscript together with MGS, CD and EF-W and revised the final version of the manuscript. EF-W designed the study, interpreted clinical, laboratory, immunological and genetics data, recognised phenotypical features and is in charge of the clinical care of patient 1 , and revised the final version of the manuscript.

Funding This work was supported by intramural funds of the CeMM Research Institute for Molecular Medicine of the Austrian Academy of Sciencies and the FWF START Programme (both to KB), and an intramural fund of the Dept. Paediatrics and Adolescent Medicine Vienna supports the work of CD and EF-W.

\section{Competing interests None.}

Patient consent Obtained.

Ethics approval Medical University Vienna Ethics Commission, Approval No. 499/2011 for immunologic and genetic characterization of pediatric patients with immunodeficiencies.

Provenance and peer review Not commissioned; externally peer reviewed.

Open Access This is an Open Access article distributed in accordance with the Creative Commons Attribution Non Commercial (CC BY-NC 3.0) license, which permits others to distribute, remix, adapt, build upon this work non-commercially, and license their derivative works on different terms, provided the original work is properly cited and the use is non-commercial. See: http://creativecommons.org/ licenses/by-nc/3.0/

\section{REFERENCES}

1 Ming JE, Stiehm ER, Graham JM Jr. Syndromic immunodeficiencies: genetic syndromes associated with immune abnormalities. Crit Rev Clin Lab Sci 2003:40:587-642.

2 Gennery AR. Immunological aspects of 22q11.2 deletion syndrome. Cell Mol Life Sci 2012;69:17-27

3 Hanley-Lopez J, Estabrooks LL, Stiehm R. Antibody deficiency in Wolf-Hirschhorn syndrome. J Pediatr 1998;133:141-3.

4 Andries S, Sartenaer D, Rack K, Rombout S, Tuerlinckx D, Gillerot Y, Van Maldergem L. Pure terminal duplication of the short arm of chromosome 19 in a boy with mild microcephaly. J Med Genet 2002;39:E60.

5 Auvin S, Holder-Espinasse M, Lamblin MD, Andrieux J. Array-CGH detection of a de novo 0.7-Mb deletion in 19p13.13 including CACNA1A associated with mental retardation and epilepsy with infantile spasms. Epilepsia 2009:50:2501-3.

6 Brown J, Horsley SW, Jung C, Saracoglu K, Janssen B, Brough M, Daschner M, Beedgen B, Kerkhoffs $G$, Eils R, Harris PC, Jauch A, Kearney L. Identification of a subtle $t(16 ; 19)(p 13.3 ; p 13.3)$ in an infant with multiple congenital abnormalities using a 12-colour multiplex FISH telomere assay, M-TEL. Eur J Hum Genet 2000:8:903-10.
7 Byrne JLB, Korn GA, Dev VG, Bunch GM, Brooks K, Friedman JM, Harrod MJE. PARTIAL TRISOMY-19P. Am J Hum Genet 1980;32:A64.

8 Dolan M, Mendelsohn NJ, Pierpont ME, Schimmenti LA, Berry SA, Hirsch B. A nove microdeletion/microduplication syndrome of 19p13.13. Genet Med 2010;12:503-11.

9 Puvabanditsin S, Garrow E, Brandsma E, Savla J, Kunjumon B, Gadi I. Partial trisomy 19p13.3 and partial monosomy 1p36.3: Clinical report and a literature review. Am J Med Genet A 2009;149A:1782-5.

10 Quigley DI, Kaiser-Rogers K, Aylsworth AS, Rao KW. Submicroscopic deletion 9 (q34.3) and duplication 19(p13.3): identified by subtelomere specific FISH probes. Am J Med Genet A 2004;125A:67-72.

11 Salbert BA, Solomon M, Spence JE, Jackson-Cook C, Brown J, Bodurtha J. Partial trisomy 19p: case report and natural history. Clin Genet 1992;41:143-6.

12 Stratton RF, DuPont BR, Olsen AS, Fertitta A, Hoyer M, Moore CM. Interstitia duplication 19p. Am J Med Genet 1995:57:562-4.

13 Siggberg L, Ala-Mello S, Jaakkola E, Kuusinen E, Schuit R, Kohlhase J, Bohm D, Ignatius J, Knuutila S. Array CGH in molecular diagnosis of mental retardation-a study of 150 finnish patients. Am J Med Genet A 2010;152A:1398-410.

14 Arkwright PD, Gennery AR. Ten warning signs of primary immunodeficiency: a new paradigm is needed for the 21st century. Ann N Y Acad Sci 2011;1238:7-14.

15 Conley ME, Notarangelo LD, Etzioni A. Diagnostic criteria for primary immunodeficiencies. Representing PAGID (Pan-American Group for Immunodeficiency) and ESID (European Society for Immunodeficiencies). Clin Immunol 1999:93:190-7.

16 de Vries E. Patient-centred screening for primary immunodeficiency, a multi-stage diagnostic protocol designed for non-immunologists: 2011 update. Clin Exp Immunol 2012;167:108-19.

17 Farmand $\mathrm{S}$, Baumann $\mathrm{U}$, von Bernuth $\mathrm{H}$, Borte $\mathrm{M}$, Foerster-Waldl $\mathrm{E}$, Franke $\mathrm{K}$ Habermehl P, Kapaun P, Klock G, Liese J, Marks R, Muller R, Nebe T, Niehues T, Schuster V, Warnatz K, Witte T, Ehl S, Schulze I, Association of the Scientific Medical Societies in G. [Interdisciplinary AWMF guideline for the diagnostics of primary immunodeficiency]. Klin Padiatr 2011;223:378-85

18 Krudewig J, Baumann U, Bernuth von H, Borte M, Burkhard-Meier U, Dueckers G, Foerster-Waldl E, Franke K, Habermehl P, Honig M, Kern W, Kosters K, Kugel K, Lehrnbecher T, Liese J, Marks R, Muller GA, Muller R, Nadal D, Peter HH, Pfeiffer-Kascha D, Schneider M, Sitter H, Spath P, Wahn V, Welte T, Niehues T. [Interdisciplinary AWMF guideline for the treatment of primary antibody deficiencies]. Klin Padiatr 2012;224:404-15.

19 Kuzmina Z, Greinix HT, Weigl R, Kormoczi U, Rottal A, Frantal S, Eder S, PickI WF Significant differences in B-cell subpopulations characterize patients with chronic graft-versus-host disease-associated dysgammaglobulinemia. Blood 2011;117: 2265-74.

20 Salzer E, Daschkey S, Choo S, Gombert M, Santos-Valente E, Ginzel S, Schwendinger M, Haas OA, Fritsch G, Pickl WF, Forster-Waldl E, Borkhardt A, Boztug K, Bienemann K, Seidel MG. Combined immunodeficiency with life-threatening EBV-associated lymphoproliferative disorder in patients lacking functional CD27. Haematologica 2013;98:473-8

21 Fauth C, Gribble SM, Porter KM, Codina-Pascual M, Ng BL, Kraus J, Uhrig S, Leifheit J, Haaf T, Fiegler H, Carter NP, Speicher MR. Micro-array analyses decipher exceptional complex familial chromosomal rearrangement. Hum Genet 2006:119:145-53.

22 Flicek P, Ahmed I, Amode MR, Barrell D, Beal K, Brent S, Carvalho-Silva D, Clapham P, Coates G, Fairley S, Fitzgerald S, Gil L, Garcia-Giron C, Gordon L, Hourlier T, Hunt $S$, Juettemann T, Kahari AK, Keenan S, Komorowska M, Kulesha E, Longden I, Maurel T, McLaren WM, Muffato M, Nag R, Overduin B, Pignatelli M, Pritchard B, Pritchard E, Riat HS, Ritchie GR, Ruffier M, Schuster M, Sheppard D, Sobral D, Taylor K, Thormann A, Trevanion S, White S, Wilder SP, Aken BL, Birney E, Cunningham F, Dunham I, Harrow J, Herrero J, Hubbard TJ, Johnson N, Kinsella R, Parker A, Spudich G, Yates A, Zadissa A, Searle SM. Ensembl 2013. Nucleic Acids Res 2013:41(Database issue):D48-55.

23 Al-Herz W, Bousfiha A, Casanova JL, Chapel H, Conley ME, Cunningham-Rundles C, Etzioni A, Fischer A, Franco JL, Geha RS, Hammarstrom L, Nonoyama S, Notarangelo LD, Ochs HD, Puck JM, Roifman CM, Seger R, Tang ML. Primary immunodeficiency diseases: an update on the classification from the international union of immunological societies expert committee for primary immunodeficiency. Front Immunol 2011:2:54.

24 Emanuel BS, McDonald-McGinn D, Saitta SC, Zackai EH. The 22q11.2 deletion syndrome. Adv Pediatr 2001:48:39-73.

25 Gao S, Li X, Amendt BA. Understanding the role of tbx1 as a candidate gene for 22q11.2 deletion syndrome. Curr Allergy Asthma Rep 2013;13:613-21.

26 Yang T, Ramocki MB, Neul JL, Lu W, Roberts L, Knight J, Ward CS, Zoghbi HY, Kheradmand F, Corry DB. Overexpression of methyl-CpG binding protein 2 impairs T(H)1 responses. Sci Trans/ Med 2012:4:163ra58.

27 Ram G, Chinen J. Infections and immunodeficiency in Down syndrome. Clin Exp Immunol 2011;164:9-16.

28 Louis AG, Gupta S. Primary selective IgM deficiency: an ignored immunodeficiency. Clin Rev Allergy Immunol 2013 [Epub ahead of print].

29 Dale DC, Person RE, Bolyard AA, Aprikyan AG, Bos C, Bonilla MA, Boxer LA, Kannourakis G, Zeidler C, Welte K, Benson KF, Horwitz M. Mutations in the gene 
encoding neutrophil elastase in congenital and cyclic neutropenia. Blood 2000;96:2317-22.

30 Horwitz MS, Corey SJ, Grimes HL, Tidwell T. ELANE mutations in cyclic and severe congenital neutropenia: genetics and pathophysiology. Hematol Oncol Clin North Am 2013:27:19-41, vii.

31 Jones-Mason ME, Zhao X, Kappes D, Lasorella A, lavarone A, Zhuang Y. E protein transcription factors are required for the development of $\mathrm{CD} 4(+)$ lineage T cells. Immunity 2012;36:348-61.

32 LeBrun DP. E2A basic helix-loop-helix transcription factors in human leukemia. Front Biosci 2003:8:s206-22.

33 Boisson B, Wang YD, Bosompem A, Ma CS, Lim A, Kochetkov T, Tangye SG, Casanova JL, Conley ME. A recurrent dominant negative E47 mutation causes agammaglobulinemia and BCR- B cells. J Clin Invest 2013 [Epub ahead of print].

34 Goodwin RG, Alderson MR, Smith CA, Armitage RJ, VandenBos T, Jerzy R, Tough TW, Schoenborn MA, Davis-Smith T, Hennen K, Falk B, Cosman D, Baker E, Sutherland GR, Grabstein KH, Farrah T, Giri JG, Beckmann MP. Molecular and biological characterization of a ligand for CD27 defines a new family of cytokines with homology to tumor necrosis factor. Cell 1993;73:447-56.

35 Agematsu K, Hokibara S, Nagumo H, Shinozaki K, Yamada S, Komiyama A. Plasma cell generation from B-lymphocytes via CD27/CD70 interaction. Leuk Lymphoma 1999;35:219-25.

36 van Montfrans JM, Hoepelman Al, Otto S, van Gijn M, van de Corput L, de Weger RA, Monaco-Shawver L, Banerjee PP, Sanders EA, Jol-van der Zijde CM, Betts MR, Orange JS, Bloem AC, Tesselaar K. CD27 deficiency is associated with combined immunodeficiency and persistent symptomatic EBV viremia. J Allergy Clin Immunol 2012;129: 787-93.

37 Groth C, Drager R, Warnatz K, Wolff-Vorbeck G, Schmidt S, Eibel H, Schlesier M, Peter HH. Impaired up-regulation of CD70 and CD86 in naive (CD27-) B cells from patients with common variable immunodeficiency (CVID). Clin Exp Immunol 2002;129:133-9

38 Mayilyan KR. Complement genetics, deficiencies, and disease associations. Protein Cell 2012;3:487-96.

39 Reis ES, Falcao DA, Isaac L. Clinical aspects and molecular basis of primary deficiencies of complement component $\mathrm{C} 3$ and its regulatory proteins factor I and factor H. Scand I Immunol 2006;63:155-68.

40 Gallego MS, Zelaya G, Feliu AS, Rossetti L, Shaffer LG, Bailey KA, Bacino CA Barreiro CZ. ATR-16 due to a de novo complex rearrangement of chromosome 16 . Hemoglobin 2005;29:141-50.

41 Wilkie AO, Buckle VJ, Harris PC, Lamb J, Barton NJ, Reeders ST, Lindenbaum RH, Nicholls RD, Barrow M, Bethlenfalvay NC, Hutz MH, Tolmie JL, Weatherall DJ, Higgs DR. Clinical features and molecular analysis of the alpha thalassemia/mental retardation syndromes. I. Cases due to deletions involving chromosome band 16p13.3. Am J Hum Genet 1990;46:1112-26.

42 Wilkie AO, Lamb J, Harris PC, Finney RD, Higgs DR. A truncated human chromosome 16 associated with alpha thalassaemia is stabilized by addition of telomeric repeat (TTAGGG)n. Nature 1990;346:868-71.

43 Harteveld CL, Kriek M, Biilsma EK, Erjavec Z, Balak D, Phylipsen M, Voskamp A, di Capua E, White SJ, Giordano PC. Refinement of the genetic cause of ATR-16. Hum Genet 2007:122:283-92. 